\title{
AC 2007-623: DEVELOPMENT OF A MECHANICAL ENGINEERING UNDERGRADUATE DEGREE WITH AN EMPHASIS IN NUCLEAR AND ENERGY ENGINEERING FOR THE UNIVERSITY OF TEXAS OF THE PERMIAN BASIN
}

\section{Sheldon Landsberger, University of Texas-Austin}

Sheldon Landsberger is Director of the Nuclear Engineering Teaching Lab at the University of Texas at Austin

\section{Janet Ellzey, University of Texas-Austin}

Dr. Janet Ellzey is a professor in the Mechanical Engineering Department in the Thermal Fluids area.

\section{Brad Hull, University of Texas-Austin}

Brad Hull is a graduate student in the Mechanical Engineering Department at the University of Texas

Jessica Rosinski, University of Texas-Austin Jessica Rosinski is a junior in the Chemical Engineering Department at the University of Texas at Austin

James Wright, University of Texas-Permian Basin James Wright is the project manager of the UTPB high temeprature, teaching and research reactor. 


\title{
DEVELOPMENT OF A MECHANICAL ENGINEERING UNDERGRADUATE DEGREE WITH AN EMPHASIS IN NUCLEAR AND ENERGY ENGINEERING FOR THE UNIVERSITY OF TEXAS OF THE PERMIAN BASIN
}

\author{
Abstract \\ Energy concerns for today and the near future are becoming of ever-increasing \\ importance for engineers and scientists. Increasing energy demand and a desire to have \\ renewable, environmental-friendly energy sources are some of the major challenges \\ facing the energy industry. Along with its planned new high temperature teaching and \\ research reactor The University of Texas of the Permian Basin has the unique opportunity \\ of being able to design a new Mechanical Engineering department that will focus on all \\ the issues surrounding energy resources and production that will include a strong nuclear \\ component as well. The curriculum will incorporate application of fundamental \\ engineering principles to energy concepts in basic mechanical engineering courses, as \\ well as offer technical area electives that will provide a more in-depth look into certain \\ types energy resources. The program will meet all ABET requirements to become an \\ accredited mechanical engineering program, as well as all requirements mandated by \\ Texas legislation and UTPB.
}




\section{Introduction}

As concerns over energy reliability and availability continue to grow in today's economy, the energy industry presents many opportunities for young engineers. The University of Texas of the Permian Basin (UTPB) has decided to construct a Mechanical Engineering curriculum that will focus on many different issues facing the energy industry today and in the future. UTPB is planning to get a contract for a nuclear reactor, which will be the cornerstone of the department and provide research opportunities to faculty and students. Although nuclear energy will certainly be one focus of the department, it will not be the only form of energy that will be available for students to explore. The department will also offer technical elective courses featuring wind energy, petroleum engineering, solar energy, hydroelectric energy, as well as other forms of "renewable" energy.

This paper outlines the general process taken in construction of the proposed curriculum. Some topics include fulfillment of all state, school, and accreditation board requirements by the proposed courses, incorporation of energy ideas into fundamental mechanical engineering courses, and selection of technical area electives that provide a broad range of energy specific topics and ideas. The end result of this development is a proposed comprehensive curriculum that focuses on energy issues, complete with course descriptions and suggested texts, which should be capable of meeting all requirements.

\section{Requirements}

The most difficult task in constructing a mechanical engineering curriculum that offers a wide range of energy applications is making sure that curriculum can still meet the necessary requirements set forth by UTPB's general requirements, as well The Accreditation Board for Engineering and Technology (ABET). This section serves to outline all these requirements and how they will be met.

The Texas State Legislature requires that a certain "core curriculum" must be met by any public institution of higher learning. UTPB has it's own requirements for any undergraduate program, which consequently meet all of the legislative requirements as well. These requirements consist of 44 semester credit hours in ten categories and are listed in Table 1. A complete description of the requirement set forth by the legislature can be found in Appendix A.

Along with the general requirements set forth by the state and UTPB, there are also certain additional requirements set forth by The Accreditation Board for Engineering and Technology (ABET) that must be met if the program wishes to become accredited. Accreditation is important in particular for engineers because graduation from an accredited program is a requirement for obtaining a professional engineer (PE) license after graduation.

The requirements set forth by ABET are very general in nature and very much a matter of interpretation. The complete requirements from ABET can be found in Appendix B. 
These requirements concern program objectives, assessment, facilities, faculty, and financial resources, as well as curriculum. The most specific requirements

Table 1. UTPB's general undergraduate requirements.

\begin{tabular}{||ll||}
\hline Composition/Written Communication & 6 credits \\
History (United States) & 6 credits \\
Literature & 3 credits \\
Mathematics (college algebra or above) & 3 credits \\
Mathematics (computing, logic, statistics, & \\
math above college algebra) & 3 credits \\
Physical and Biological Sciences & \\
(any two courses with labs) & 8 credits \\
Political Sci. (U.S., state and local gov't.) & 6 credits \\
Visual and Performing Arts & 3 credits \\
Oral Communication (Speech) & 3 credits \\
Social Science & 3 credits \\
TOTAL HOURS REOUIRED & $\mathbf{4 4}$ credits \\
\hline \hline
\end{tabular}

concerning curriculum from ABET can be found in Criterion 4: Professional Component, which is in Section II: Basic Level Accreditation Criteria. This section is reproduced below:

Criterion 4. Professional Component

The Professional Component requirements specify subject areas appropriate to engineering but do not prescribe specific courses. The engineering faculty must assure that the program curriculum devotes adequate attention and time to each component, consistent with the objectives of the program and institution. Students must be prepared for engineering practice through the curriculum culminating in a major design experience based on the knowledge and skills acquired in earlier coursework and incorporating engineering standards and realistic constraints that include most of the following considerations: economic; environmental; sustainability; manufacturability; ethical; health and safety; social; and political. The professional component must include

(a) one year of a combination of college level mathematics and basic sciences (some with experimental experience) appropriate to the discipline

(b) one and one-half years of engineering topics, to include engineering sciences and engineering design appropriate to the student's field of study

(c) a general education component that complements the technical content of the curriculum and is consistent with the program and institution objectives. 
ABET lists requirements in years rather than credits or hours simply because many schools use different measures in their curriculum. For a 126 credit hour, four year undergraduate degree, one year is the equivalent of $126 / 4=31.5$ hours.

On top of these general ABET requirements for a mechanical engineering department, The American Society of Mechanical Engineers (ASME) also has included the following, which are still considered to be part of the accreditation criteria.

\section{PROGRAM CRITERIA FOR MECHANICAL ENGR. PROGRAMS}

Submitted by The American Society of Mechanical Engineers

These program criteria apply to engineering programs including "mechanical" or similar modifiers in their titles.

\section{Curriculum}

Graduates must have demonstrated knowledge of chemistry and calculus-based physics with depth in at least one;

ability to apply advanced mathematics through multivariate calculus and differential equations;

familiarity with statistics and linear algebra;

the ability to work professionally in both thermal and mechanical systems areas including the design and realization of such systems.

2. Faculty

Faculty responsible for the upper-level professional program must demonstrate that they are maintaining currency in their specialty area.

As stated previously, it is the intent to have a mechanical engineering program that focuses on energy issues. All the requirements set forth by UTPB, ABET, and ASME do not differentiate between a program that focuses on energy and a "traditional" mechanical engineering program. Because of this, careful consideration was given first and foremost to meeting the requirements, then having sufficient hours in the form of energy courses or technical electives so that the program will in fact be a true mechanical engineering department that focuses on energy issues. Care was also given to create a program that was not too eccentric, especially in the first two years, so that credit transfer to other universities would not cause too many problems.

A general outline of the proposed curriculum, presented in Table 2, is given on the next two pages in order to show what courses go to meet certain requirements. Individual course descriptions will be discussed in subsequent sections. An alternative view of how certain requirements will be met can be found in subsequent Tables 3-6. 
Table 2. Proposed undergraduate ME curriculum, including requirements met by each course.

1st SEMESTER

\begin{tabular}{|l|l|c|l|}
\hline Department & Course & Hrs & Requirements Met \\
\hline Math & DIFF/INTEGRAL CALC. & 4 & UTPB Math, ABET Math \& Sci. \\
\hline Chemisty & CHEMISTRY I & 3 & UTPB Nat. Sci., ABET Math \& Sci. \\
\hline Chemisty & CHEMISTRY I LAB & 1 & UTPB Nat. Sci., ABET Math \& Sci. \\
\hline Rhetoric & RHETORIC AND COMP. & 3 & UTPB Compostion and Writing \\
\hline Social Science & SOCIAL SCI. ELECTIVE & 3 & UTPB Social Science \\
\hline ME & ENGR. DESIGN & 3 & UTPB Arts, ABET Engr. Design \\
\cline { 2 - 3 } & TOTAL & $\mathbf{1 7}$ & \multicolumn{2}{|c}{} \\
\cline { 2 - 3 } & \multicolumn{2}{|l}{} &
\end{tabular}

2nd SEMESTER

\begin{tabular}{|l|l|c|l|}
\hline Department & Course & Hrs & Requirements Met \\
\hline Engr. Mech. or ME & STATICS & 3 & ABET Engr. Sci. \\
\hline Math & SEQ., SERIES, MULTI. CALC & 4 & UTPB Math, ABET Math \& Sci. \\
\hline Physics & PHYSICS I & 3 & ABET Math \& Sci., ABET Physics \\
\hline Physics & PHYSICS I LAB & 1 & ABET Math \& Sci., ABET Physics \\
\hline Nat. Sci. & NATURAL SCI. ELECT. I & 3 & UTPB Nat. Sci., ABET Math \& Sci. \\
\hline Nat. Sci. & NATURAL SCI. ELECT. I LAB & 1 & UTPB Nat. Sci., ABET Math \& Sci. \\
\cline { 2 - 3 } & TOTAL & $\mathbf{1 5}$ & \multicolumn{2}{|l}{} \\
\cline { 2 - 3 } & &
\end{tabular}

3rd SEMESTER

\begin{tabular}{|l|l|c|l|}
\hline Department & Course & Hrs & Requirements Met \\
\hline English/Lit & MASTERWORKS LIT. (W) & 3 & UTPB Literature, Writing Comp. \\
\hline Engr. Mech. or ME & MECH. OF SOLIDS & 3 & ABET Engr. Sci. \\
\hline Math & DIFFERENTIAL EQUATIONS & 4 & ABET Diff. Eq'n. \\
\hline ME & THERMODYNAMICS & 3 & ABET Engr. Sci. \\
\hline Physics & PHYSICS II & 3 & ABET Math \& Sci., ABET Physics \\
\hline Physics & PHYSICS II LAB & 1 & ABET Math \& Sci., ABET Physics \\
\cline { 1 - 2 } & TOTAL & $\mathbf{1 7}$ & \multicolumn{2}{|l}{} \\
\cline { 2 - 3 } & & \multicolumn{2}{|l}{}
\end{tabular}

4th SEMESTER

\begin{tabular}{|l|l|c|l|}
\hline Department & Course & Hrs & Requirements Met \\
\hline ME & MATERIALS ENGR. & 3 & ABET Engr. Sci. \\
\hline ME & MAT. ENGR. LAB & 1 & ABET Engr. Sci. \\
\hline ME & ENGR. STATS. AND DATA PROC. & 3 & ABET Math \& Sci., ASME Statistics \\
\hline ME & KINEMATICS AND DYNAMICS & 3 & ABET Engr Design \\
\hline ME & FLUID MECH. & 3 & ABET Engr. Sci. \\
\hline ME & FLUID MECH. LAB & 1 & ABET Engr. Sci. \\
\hline Government & AMERICAN GOV'T I & 3 & UTPB Gov't \\
\cline { 2 - 3 } & TOTAL & $\mathbf{1 7}$ & \multicolumn{2}{|l}{} \\
\cline { 2 - 3 } & & \multicolumn{2}{|l}{} \\
\cline { 2 - 3 } & & &
\end{tabular}

5th SEMESTER

\begin{tabular}{|l|l|c|l|}
\hline Department & Course & Hrs & Requirements Met \\
\hline Elect. Engr. or ME & ELECTRO-MECHANICS & 3 & ABET Engr. Sci. \\
\hline ME & COMP. METH. \& LINEAR ALG. & 3 & ABET Engr Sci., ASME Linear Alg. \\
\hline ME & MACHINE ELEMENTS & 3 & ABET Engr. Design \\
\hline ME & HEAT TRANSFER & 3 & ABET Engr. Sci. \\
\hline ME & HEAT TRANSFER LAB & 1 & ABET Engr. Sci. \\
\hline Government & AMERICAN GOV'T II & 3 & UTPB Gov't \\
\cline { 2 - 3 } & TOTAL & $\mathbf{1 6}$ & \multicolumn{2}{|l}{} \\
\cline { 2 - 3 } & &
\end{tabular}


6th SEMESTER

\begin{tabular}{|c|c|c|c|}
\hline Department & Course & Hrs & Requirements Met \\
\hline ME & $\begin{array}{l}\text { ENGR. COMM. \& TECH. WRIT. } \\
\text { (W) }\end{array}$ & 3 & UTPB Oral Comm., Writing Comp. \\
\hline $\mathrm{ME}$ & THERMAL FLUID SYSTEMS & 3 & ABET Engr. Sci. \\
\hline $\mathrm{ME}$ & ENERGY SYSTEMS & 4 & ABET Engr. Sci. \\
\hline $\mathrm{ME}$ & DYN. SYS. AND CONTROLS & 3 & ABET Engr. Design \\
\hline ME & SENSORS AND INST. & 1 & ABET Engr. Sci. \\
\hline \multirow[t]{2}{*}{ ME } & SENSORS AND INST. LAB & 2 & ABET Engr. Sci. \\
\hline & TOTAL & 16 & \\
\hline
\end{tabular}

7th SEMESTER

\begin{tabular}{|l|l|c|l|}
\hline Department & Course & Hrs & Requirements Met \\
\hline ME & ENGR. ECONOMICS & 3 & ABET Engr. Design \\
\hline ME & ENGR. DESG. METH. (W) & 3 & ABET Engr. Design, Writing Comp. \\
\hline ME, NS, Math & TECH. ELECT. I & 3 & ABET Engr. Sci/Design \\
\hline ME & TECH. ELECT. II & 3 & ABET Engr. Sci/Design \\
\hline History & HISTORY I (W) & 3 & UTPB History, Writing Comp. \\
\cline { 2 - 3 } & TOTAL & $\mathbf{1 5}$ & \multicolumn{1}{|l}{} \\
\cline { 2 - 3 } & &
\end{tabular}

8th SEMESTER

\begin{tabular}{|l|l|c|l|}
\hline Department & Course & Hrs & Requirements Met \\
\hline ME & FINAL DESIGN PROJECT & 4 & ABET Engr. Design, CAPSTONE \\
\hline ME & TECH. ELECT. III & 3 & ABET Engr. Sci/Design \\
\hline ME & TECH. ELECT. IV & 3 & ABET Engr. Sci/Design \\
\hline \multirow{2}{*}{ History } & HISTORY II (W) & 3 & UTPB History, Writing Comp. \\
\cline { 2 - 3 } & TOTAL & $\mathbf{1 3}$ & \multicolumn{2}{|l}{} \\
\cline { 2 - 3 } & \multicolumn{2}{|l}{} & \multicolumn{2}{|l}{} \\
\cline { 2 - 3 } & & &
\end{tabular}

Table 3. Courses meeting UTPB undergraduate curriculum requirements.

\begin{tabular}{|l|c|l|c|}
\hline \multicolumn{2}{|l}{ SUBJECT } & HRS & \multicolumn{2}{l|}{ HRS } \\
\hline LITERATURE & 3 & MASTERWORKS LIT. (W) & 3 \\
\hline MATH & 6 & $\begin{array}{l}\text { DIFF./INTEGRAL CALC. } \\
\text { SEQ., SERIES, MULTI. CALC. }\end{array}$ & 4 \\
& & ENGR. DESIGN & 3 \\
\hline VISUAL AND PERF. ARTS & 3 & AMERICAN GOV'T I & 3 \\
\hline POLITICAL SCIENCE & 6 & AMERICAN GOV'T II & 3 \\
\hline ORAL COMMUNICATION & 3 & ENGR. COMM. \& TECH. WRIT. (W) & 3 \\
\hline PHYSICAL/BIO SCIENCE & 8 & CHEMISTRY I & 3 \\
& & CHEMISTRY I LAB & 1 \\
& & NATURAL SCI. ELECT. & 3 \\
\hline SOCIAL SCIENCE & & NATURAL SCI. ELECT. LAB & 1 \\
\hline HISTORY & 3 & SOCIAL SCI. ELECT. & 3 \\
\hline COMPOSITION/WRITING & 6 & HISTORY I & 3 \\
& & HISTORY II & 3 \\
\hline
\end{tabular}


Table 4. Courses meeting ABET's math and science requirements (31.5 hours required).

\begin{tabular}{|l|c|}
\hline COURSE & HRS \\
\hline DIFF./INTEGRAL CALC. & 4 \\
SEQ., SERIES, MULTI. CALC. & 4 \\
DIFFERENTIAL EQUATIONS & 4 \\
PHYSICS I & 3 \\
PHYSICS I LAB & 1 \\
PHYSICS II & 3 \\
PHYSICS II LAB & 1 \\
CHEMISTRY I & 3 \\
CHEMISTRY I LAB & 1 \\
ENGR. STATS. AND DATA PROC. & 3 \\
NATURAL SCI. ELECT. & 3 \\
NATURAL SCI. ELECT. LAB & 1 \\
COMP. METH. \& LINEAR ALG. & 3 \\
\hline TOTAL & $\mathbf{3 4}$ \\
\hline
\end{tabular}

Table 5. Courses meeting ABET's engineering science requirements ( 24 hours required).

\begin{tabular}{|l|c|}
\hline COURSE & HRS \\
\hline THERMODYNAMICS & 3 \\
MATERIALS ENGR. & 3 \\
MAT. ENGR. LAB & 1 \\
FLUID MECH. & 3 \\
FLUID MECH. LAB & 1 \\
ELECTRO-MECHANICS & 3 \\
COMP. METH. \& LINEAR ALG. & 3 \\
HEAT TRANSFER & 3 \\
HEAT TRANSFER LAB & 1 \\
THERMAL FLUID SYSTEMS & 3 \\
ENERGY SYSTEMS & 4 \\
\hline TOTAL & $\mathbf{2 8}$ \\
\hline
\end{tabular}

Table 6. Courses meeting ABET's engineering design requirements ( 24 hours required)

\begin{tabular}{|l|c|}
\hline COURSE & HRS \\
\hline STATICS & 3 \\
MECH. OF SOLIDS & 3 \\
ENGR. DESIGN & 3 \\
KINEMATICS AND DYNAMICS & 3 \\
MACHINE ELEMENTS & 3 \\
DYN. SYS. AND CONTROLS & 3 \\
ENGR. DESG. METH. (W) & 3 \\
FINAL DESIGN PROJECT & 4 \\
ENGR. ECONOMICS & 3 \\
\hline TOTAL & $\mathbf{2 8}$ \\
\hline
\end{tabular}


In satisfying all the requirements, several issues regarding specific courses need to be considered. The final three hours of the UTPB rhetoric and composition requirements are met by counting five courses that contain a significant writing component, denoted by a "W", instead of a second rhetoric and composition course. The University of Texas at Austin has similar rhetoric and composition requirements and the mechanical engineering curriculum meets this requirement in a similar manner.

Two courses in particular that are listed in the ABET math and science requirement may need special attention to make sure they can be counted in the manner in which they are intended. Engineering Statistics and Data Processing and Computational Methods and Linear Algebra are both designed to be courses in which mathematical concepts are used in engineering applications. Both of these courses are somewhat open to interpretation as to whether they can be considered true "math" courses, but with some consideration in course planning they should be able to be counted toward ABET's math and science requirement. UT Austin counts Probability and Statistics toward this math requirement, and has a separate linear algebra course that is not required, but rather offered as an elective. These two courses are also important because they go to satisfy the ASME portion of the ABET criteria, which states students "must have familiarity with statistics and linear algebra."

The ABET requirement for one and one-half years (47.25 credit hours) of engineering topics was split into engineering design and engineering science courses, simply because ABET states that there must be an amount of each that is "appropriate to the student's field of study." Once again, it is relatively open to interpretation as to what courses are design-based and what courses are engineering science.

In the event that changes need to be made in order to meet any of necessary requirements, there are several options. The first option is to change one of the technical elective courses, of which there are currently four, to a natural science or math elective. This should however be a last resort, since these technical area electives are the courses that will focus mainly on energy issues and topics. Another option is to eliminate, or perhaps modify Engineering Economics. Although this course could be useful in the context of the role of business in energy systems, it currently is not required by any entity, and is currently only counted toward ABET engineering design course requirements, which only require approximately 24 hours (currently have 28 hours). The final option is to simply modify an existing course. For instance, Energy Systems, a four-hour course in the student's sixth semester, is designed to provide a general overview of a wide range of energy systems, issues, and applications, with the hope of allowing the student to see what type of technical area electives to focus on in the subsequent semesters. In the event that Engineering Economics is eliminated, some of the topics could be rolled into another course, such as Energy Systems. 


\section{Required Courses}

The proposed curriculum will integrate energy topics and fundamentals into the mechanical engineering catalog by two methods: application of basic and fundamental principles to energy systems in fundamental mechanical engineering courses, such as Thermodynamics, Fluid Mechanics, and Heat Transfer, and by offering a wide array of technical elective courses for students to take during their last several semesters. The proposed curriculum has already been presented in the context of fulfilling necessary requirements; this section serves to provide a more in depth look at individual required courses (technical electives are discussed in the following section) that are to be offered. For some upper level courses, a course description and possible texts are included.

The first four semesters of the curriculum are very similar to many mechanical engineering curricula across the country, and thus will not be discussed in detail. While these courses will introduce fundamental principles in mechanical engineering, they also present an opportunity to apply some of these principles to basic energy systems. The faculty will ultimately be responsible for the topics covered in each respective course, however just as an example, in Fluid Mechanics students will be introduced to the concepts of lift and drag. Typically, these principles are applied to simple airfoils, airplane wings or other common systems in homework problems and projects. Instead of the latter, these concepts could be applied to wind energy systems. Similarly, faculty could introduce pipe flow fundamentals in the context of petroleum engineering, radiation heat transfer in the context of solar energy systems, and so on. A very general outline that presents some of these possibilities is available in Appendix C.

The one course that is somewhat unique in the first two years of this proposed curriculum is Engineering Statistics and Data Processing. Most mechanical engineering curricula contain some type of statistics course because of the ASME requirements, however in many cases these courses are taught in different departments and are often not extremely useful in mechanical engineering applications. The purpose if this course as it was designed is to first and foremost meet the ASME requirement, but also to focus on more applicable statistic concepts such as distribution functions, mathematical deviations, and other concepts that are pertinent to analyzing data.

There are several courses in the fifth semester that are somewhat unique. Electromechanics is a course that in many mechanical engineering catalogs is called something along the lines of "Electrical Engineering." Typically this course is offered through an electrical engineering department and focuses on electric circuits and related topics, but often does not cover topics that are most relevant to mechanical engineers such as AC and DC power supply, electric motors and generators, torque and speed relations, power factors, and the like. A possible course description for Electro-mechanics is provided below: 


\section{Electro-mechanics}

Introduces electrical engineering topics most relevant to mechanical engineering and energy system applications. Electromagnetism, power supply, AC and DC systems, electric motors, torque-speed relations, electric generators, transformers, and other relevant topics.

\section{Suggested text:}

Harter, J., Electromechanics: Principles, Concepts, and Devices, Prentice Hall, 1994

Computational Methods and Linear Algebra is another course that is relatively unique. This course is designed to meet the ASME requirement for linear algebra, as well as offer application of many of the concepts learned in linear algebra to numerical analysis. A possible course description is presented below:

\section{Computational Methods and Linear Algebra}

Linear algebra fundamentals and matrix operations applied to computational methods. Introduction to computationally modeling physical systems using relevant programming methods.

\section{Suggested Texts:}

Lay, D., Linear Algebra and its Applications, Addison Wesley, 2002.

Dettman, J., Introduction to Linear Algebra and Differential Equations, Dover Publications, 1986.

Schafer, M., Computational Engineering-Introduction to Numerical Methods, Springer, 2006.

Jaluria, Y., Computer Methods for Engineering, Taylor and Francis, 1995.

The remaining mechanical engineering courses in the fifth semester, Machine Elements and Heat Transfer, are both found in most mechanical engineering curricula. Machine Elements is intended to introduce basic machine component design and mechanical components. Heat Transfer introduces the all the basic modes of heat transfer, as well as applications such as heat exchangers.

In the sixth semester, the first course focusing solely on energy issues is available. Energy Systems is designed to be course that provides an introduction to many types of energy systems and methods. This course should serve to provide students a basic understanding of all types of energy systems, thus allowing students to decide what technical elective courses, which will be much more focused, they want to take. A possible course description for Energy Systems is presented below: 


\section{Energy Systems}

Provides and overview of crucial issues concerning energy production and consumption. A brief introduction into many types of energy systems. Regulatory laws, as well as economic and environmental issues.

\section{Suggested Texts:}

Boyle, G., Everett, B., Ramage, J., Energy Systems and Sustainability, Oxford University Press, 2003.

Fanchi, J., Energy in the $21^{\text {st }}$ Century, World Scientific Publishing Company, 2005.

Sensors and Instrumentation is a course designed to be very "hands-on". Students will have been exposed to several methods of measurement in previous laboratory courses; this course, along with the accompanying laboratory course, will provide a more in-depth look at various methods measurement and data analysis. A possible course description is given below:

\section{Sensors and Instrumentation (including laboratory)}

Provides an in depth look into taking different types of measurement, including temperature, pressure, velocity, force, acceleration, flow, torque, and power. Different types of instrumentation and processes. Data acquisition and signal conversion, error analysis.

\section{Suggested text:}

Turner, J., Hill, M., Instrumentation for Engineers and Scientists, Oxford University Press, 1999.

The remaining courses listed in the sixth semester are once again rather standard courses for a mechanical engineering curriculum. Engineering Communication and Technical Writing is designed to be a project-based course in which students learn the essentials of technical communication, both oral and written. Thermal Fluid Systems is basically a combination of fundamentals from Fluid Mechanics, Heat Transfer, and Thermodynamics. This course also covers power and refrigeration cycles, ideal gas mixtures, psychrometrics, and fundamentals of combustion. Dynamic Systems and Controls introduces lumped physical systems models, energy transfer ideas, and feedback control.

The seventh semester contains two required mechanical engineering courses, Engineering Economics and Engineering Design Methodology. Engineering Economics has already been mentioned in the requirements section. As it stands now, this course is designed to examine economic issues regarding energy systems, plants, and processes. Engineering Design Methodology is designed to be somewhat of a reverse engineering course in 
which students learn to apply methodology in the design process. This course is listed as a significant writing component since the course will be very project based and will require writing of reports, memorandums, or progress updates.

The final semester has only one required mechanical engineering course, entitled Final Design Project. This is commonly referred to a "capstone" course, in which students apply their knowledge in a design or research project. This course offers an opportunity for the department to allow companies in the energy industry to sponsor certain projects, which the students will carry out.

\section{Technical Elective Courses}

The technical elective courses are designed to provide in-depth discussion of various types of energy systems and applications, including petroleum engineering, nuclear engineering, wind energy, solar energy, hydro-electric and tidal power, and perhaps other types of energy sources such as biomass, hydrogen fuel cells, or geothermal energy. Currently, the curriculum provides four, three-hour technical electives. The development and realization of these courses will be strongly dependent on the faculty members UTPB hires. Some possible course descriptions are presented below and on the following pages:

\section{Introduction to Ocean Engineering and Technology}

Physical oceanography including saltwater properties and distributions, ocean circulations and geostrophic flows, influence of other factors such as heating and wind. Ocean wave properties and propagation, acoustics. Introduction to devices and methods used, such as differentiation of sound, SONAR, and surveying equipment.

\section{Suggested texts:}

Ogilvie, T. F., Fluid Mechanics for Ocean Engineers, 1996. Smits, A. J., A Physical Introduction to Fluid Mechanics, Wiley, 2000.

Urick, R. J., Principles of Underwater Sound, 3rd ed., New York: McGraw-Hill, 1983.

Knauss, J. A., Introduction to Physical Oceanography, Prentice Hall, 1997.

Mellor, G. L., Introduction to Physical Oceanography, Woodbury, NY: AIP Press, 1996.

Cushman-Roisin, B., Introduction to Geophysical Fluid Dynamics, Prentice Hall, 1994. 


\section{Fundamentals of Energy Conversion and Consumption}

Focus on energy production and consumption, with emphasis on economic and environmental topics, including regulations. General comparison between types of energy production. Advanced topics.

\section{Suggested Texts:}

Decher, R., Energy Conversion: Systems, Flow Physics and Engineering, Oxford University Press, 1994.

Tester, J., Drake, M. W. Golay, M. J. Driscoll, W. A. Peters. Sustainable Energy - Choosing Among Options. Cambridge, MA: MIT Press, 2005

\section{Advanced Electro-Mechanics and Energy Conversion, including a laboratory course}

In depth theory and analysis of different types of electric machinery, including all types of motors, generators, and transformers. Synchronicity, frequency, phase, induction, power factors, torque-speed characteristics, motor/generator control, cooling, and measurement of these in the accompanying lab course. Advanced topics.

\section{Suggested text:}

Harter, J., Electromechanics: Principles, Concepts, and Devices, Prentice Hall, 1994 (same as for required Electromechanics course).

\section{Fundamentals of Wind Energy}

Holistic examination of wind energy considerations including types of wind and driving forces, measurement, variation, turbine design and placement, wind farm design and operation, manufacturing and operation, and any other relevant topics. Brief examination of energy conversion specific to wind energy, with a more in depth examination available in Advanced Electro-Mechanics and Energy Conversion, a course that should be considered very applicable to this technology. 


\section{Suggest Texts:}

Heier, S., Waddington, R., Grid Integration of Wind Energy Systems, John Wiley and Sons, 2006

Mathew, S., Wind Energy: Fundamentals, Resource Analysis, and Economics, Springer, 2006.

Burton, T., Sharpe, D., Jenkins, N., Bossanyi, E., Wind Energy Handbook, John Wiley and Sons, 2001.

Gasch, R., Twele, J., Wind Power Plants: Fundamentals, Design, Construction and Operation, Earthscan, 2004.

\section{Solar Energy Fundamentals}

Introduces most aspects of solar energy theory and application. Solar radiation, collection of solar energy, thermal energy storage, costs analysis, and photovoltaic cells.

\section{Suggested Texts:}

Hall, Bannerot, and Vliet, Thermal Energy Systems Design and Analysis, McGraw-Hill, 1982.

Duffie, J., Beckman, W., Solar Engineering of Thermal Processes, Wiley-Interscience, 1991.

Goswami, D., Principles of Solar Engineering, Taylor and Francis, 2000.

\section{Hydrogen Fuel Cell Technology}

Basic science and technology concerning hydrogen production methods and fuel cell technology. Fuel cell operations and challenges.

\section{Suggested texts:}

O'Hayre, R., Cha, S., Colella, W., Prinz, F., Fuel Cell Fundamentals, Wiley, 2005.

Hoogers, G., Fuel Cell Technology Handbook, CRC, 2002.

\section{Reservoir Engineering}

Basic introductory topics concerning reservoir engineering as it pertains to petroleum engineering.

Suggested Texts:

Dake, L., Fundamentals of Reservoir Engineering, Elsevier Science, 2001. 


\section{Oil Exploration}

Provides an introduction to the methods, tools, and technology used in oil and natural gas exploration, surveying, and mapping.

\section{Suggested text:}

Faculty choice.

\section{Pipeline Technology and Oil Transportation}

Discusses design aspects of oil transportation technology, measurement and controls, and modeling.

\section{Suggested text:}

Faculty choice.

\section{Fuel Refining Processes}

Fuel refining processes and refinery operation. Cracking by catalytic methods, hydrocracking, alkylation. Also examines economic and environmental issues.

\section{Suggested text:}

Parkash, S., Refining Processes Handbook, Gulf Professional Publishing, 2003.

\section{Introduction to Nuclear Engineering}

Radioactivity, nuclear interactions- fission and fusion, fission reactors, nuclear power systems, nuclear power safety

\section{Suggested text}

Lamarsh, R. and Anthony J. Baratta, A. J., Introduction to Nuclear Engineering, John Wiley, 2001.

\section{Health Physics}

Atoms and x-rays; nuclei and nuclear radiations; radioactivity; nuclear reactions; interaction of radiations with physical and biological matter; radiation dosimetry; biological effects of radiation; radiation protection and regulatory standards

\section{Suggested text}

Cember, H., Introduction to Health Physics, McGraw Hill, $3^{\text {rd }}$ edition, 1996. 
Nuclear Reactor Engineering

Fundamental principles of the design and analysis of nuclear systems; introduction to the physics of nuclear reactions, chain reactions, and nuclear energy generation; heat generation and conduction within nuclear systems; heat transfer and fluid flow in nuclear systems; the thermodynamics of nuclear power; the nuclear fuel cycle; and issues related to the materials aspect of reactor engineering.

\section{Suggested Text}

Kneif, R. A, Nuclear Reactor Engineering: Theory and Technology of Nuclear Power, $2^{\text {nd }}$ edition,Taylor and Francis 1992.

\section{Health Physics Laboratory}

An introduction to the application of radiation and radiation protection instrumentation. Lecture and laboratory topics include personnel monitoring; radiation detection systems; gamma-ray spectroscopy; determination of environmental radiation; counting statistics; gamma and neutron shielding; and air sampling

\section{Suggested Text}

Landsberger, $S . M E 361 F$ Radiation and Radiation Laboratory Manual, University of Texas, 2006

Radioactive Waste Management

An introduction to radioactive waste management covering the topics of waste forms; regulation and siting; public health and environmental issues; remediation and stabilization; low and high-level waste management; air dispersion; and radioactive groundwater transport

\section{Suggested Text}

Saling, J.H and Audeen W. Fentiman, A. W., Radioactive Waste Management, $2^{\text {nd }}$ Edition, Taylor and Francis (2002) 
In addition to these technical electives, students should be allowed to take one, perhaps two, elective courses in natural science or math. Many of the energy topics are strongly related to natural science topics, and students could benefit from taking these courses.

Of all the various types of energy systems that will be examined in the technical elective courses, petroleum engineering topics represent the most difficult to incorporate into a mechanical engineering department. There are entire undergraduate programs devoted to petroleum engineering, and selecting several topics to include in the technical area electives will be challenging.

The department may wish to group some of these courses together to create sub-programs that could focus on petroleum engineering, nuclear engineering, or alternative energy. Just as well, the department may want to allow students to take whatever technical elective courses they want, with no sub-programs or restrictions.

\section{Conclusions and Recommendations}

A 126 credit hour mechanical engineering curriculum that focuses on energy issues has been proposed. The proposed curriculum should meet all necessary UTPB requirements, as well as all ABET and ASME requirements for accreditation. The curriculum should introduce energy topics by incorporating such topics into fundamental mechanical engineering courses, as well as providing a broad range of energy based technical electives.

The most pertinent recommendation is that the department should seek outside consultation, most likely from ASME, for help in making sure the proposed courses will meet all ABET requirements. Great care was taken in the development of this curriculum to ensure that these requirements could be met, but as stated previously all the requirements and fulfillment of the requirements is very much a matter of interpretation. The second recommendation is that the department creates a list of objectives and program outcomes before hiring faculty and deciding on a curriculum. A possible list of objectives and program outcomes, which was used in the creation of this proposed curriculum, is included in Appendix D. The final recommendation concerns faculty and the future of the department. UTPB should consider the overall goals of this department in terms of possibly adding a graduate program and conducting research. Given the innovative characteristics of this proposed department, and access to the nuclear reactor, UTPB could establish itself as a leader in this type of research. This should be taken into consideration when hiring faculty. 